\title{
A SCENARIO-BASED MODEL FOR THE STUDY OF COLLABORATION IN CONSTRUCTION
}

\author{
Alejandro Garcia ${ }^{1}$ and Danny Murguia ${ }^{2}$
}

\begin{abstract}
The construction sector has been widely criticized for its low productivity, fragmented structure, and adversarial relationships. To address these problems, some industry actors are adopting innovations such as lean construction, digital technologies, and collaborative contracts. However, these transformative innovations are underpinned by interorganizational collaboration within complex supply chain networks. Understanding collaboration in theory and practice is a difficult task. Therefore, this study aims to investigate factors influencing collaboration and develop a model for inter-organizational collaboration. To achieve this aim, first, a literature review on collaboration in construction was conducted. Second, qualitative data were collected via semi-structured interviews using the critical incident technique. Third, data were deductively and inductively analyzed using thematic nodes. Data showed that collaboration can be classified into four dimensions: trust, project uncertainty management, client's operational capability, and business relationships. Finally, an empirical framework was constructed using the scenario technique. Client attributes and Supply Chain Capabilities were found to be the most influential and uncertain factors. Based on these, four collaboration scenarios were developed and assessed with illustrative implications derived from the empirical data. The scenario-based model would provide a further understanding of inter-organizational collaboration within supply chains and would aid Lean Construction practitioners to develop collaborative relationships.
\end{abstract}

\section{KEYWORDS}

Collaboration, supply chain management, lean construction, relationships, scenarios.

\section{INTRODUCTION}

Over the last few years, the construction industry has experienced very rapid technological growth. However, despite major transformation efforts to meet global challenges, the industry is still known as the least efficient compared to the manufacturing sector or the total economy. On the other hand, isolated pockets of innovation will not deliver the expected transformational results (Ozorhon and Oral 2017). Practitioners require to exchange information and knowledge with other partners to achieve the benefits of innovations (Xue et al. 2018). However, little emphasis has been placed on

1 Research Assistant, Construction Management \& Technology Research Group (GETEC), Pontifical Catholic University of Peru, garcia.alejandro@ pucp.pe, orcid.org/0000-0002-1347-0824

2 Assistant Professor, Construction Management \& Technology Research Group (GETEC), Pontifical Catholic University of Peru, dmurguia@ pucp.pe, orcid.org/0000-0003-1009-4058 
the collaborative practices to ensure this exchange and on the collaborative environments where efficacy and efficiency flourish. As such, previous studies suggest that effective collaboration between the project owner and the contractor is essential for project success. Karlsson and Kindbom (2018) claimed that parties involved should strategically work to gather timely feedback before the project is launched.

Previous research has acknowledged that collaboration is a complex concept. Moreover, there are divergent perspectives of collaboration in construction (Hughes et al. 2012). Xue et al. (2018) identified several types of collaborative working such as teamwork, partnership, project alliance, joint venture, strategic alliance, coalition, and supply chain management. Moreover, actors from various disciplines make sense of collaboration depending on their previous experience and current values. Thus, divergent interpretations of the constituents of collaboration become evident in the decision-making process, where stakeholders vary their intent and degree of involvement. Willis and Alves (2019) argued that collaboration keywords in contracts would promote collaborative behaviors in practice. They showed that Design-Build (DB) and Integrated Project Delivery (IPD) contracts have far more collaborative language than traditional DesignBid-Build (DBB) contracts. This suggests that owners who choose the project delivery method should carefully decide on the language to be used in contracts. However, this research argues that industry actors poorly understand both the concept of collaboration and collaborative practices. Therefore, it is necessary to broaden the understanding of collaboration to have a clearer picture of inter-organizational collaboration. For this reason, the main objective of this study was to develop a model for inter-organizational collaboration that can be used to foster collaborative behaviors among project participants.

\section{LITERATURE REVIEW}

\section{DEFINITIONS}

Previous studies highlighted the difference between coordination, cooperation, and collaboration. Roberts and Bradley (1991) conceptualized collaboration as "an interactive process that has a shared transmutational purpose with the characteristics of having an explicit voluntary affiliation, joint decision-making, a need for agreed norms, and that has a temporal structure toward the same end". On the other hand, coordination is defined as the planning or arranging of different activities involving two or more parties, and cooperation explains how an inter-organizational relationship occurs between project participants who are not commonly related by vision or mission, resulting in the creation of separate projects with independent structures (Schöttle et al. 2014). However, Haghsheno et al. (2020) recently argued again that "collaboration goes beyond as it describes the common vision to create a common project organisation with a jointly defined structure and to create a project culture based on trust, and transparency". Therefore, in this research, collaboration is defined as a process of inter-organizational interaction that involves the effective and transparent transfer of information and knowledge so that working together will increase value for each independent unit.

\section{FACTORS INFLUENCING COLLABORATION}

Collaboration is difficult to achieve in the construction industry due to low margins and a lack of trust between stakeholders. Previous studies have catalogued the most important factor influencing collaboration. For example, Deep et al. (2019) claimed that collaboration was strongly associated with trust, commitment of the organization to a 
contract, and reliability of the supplier. Moreover, Haaskjold et al. (2019) found that quality of communication, project uncertainty, client's operational capability, change orders and trust represent the most influential factors in collaboration. Similarly, Eskerod et al. (2010) argued that the most representative collaboration antecedents in the field of project management were clear roles and processes, trust, physical and cultural proximity, alignment of incentives, commitment to the project, goal congruence, conflict resolution, and expectations fulfillment. Likewise, Schöttle and Gehbauer (2012) found that uncertainty had to be counteracted by an incentive system to develop a collaborative project environment. Knapp et al. (2014) proposed that the owner's representative plays a critical role in the active promotion of harmony, collaboration, and cooperation among all entities performing on the project. To support a collaborative approach, Schöttle and Tillmann (2018) collected findings from two case studies in which an explicit process for goal setting and tracking was used. These previous studies suggest that collaboration factors are linked to social and managerial dimensions as detailed in Table 1.

Table 1: Factors Influencing Collaboration

\begin{tabular}{|c|c|c|}
\hline Factor & Description & Author(s) \\
\hline $\begin{array}{l}\text { Quality of } \\
\text { communication }\end{array}$ & $\begin{array}{l}\text { Allows all parties to share and spread the objectives of } \\
\text { project organization, responsibilities, and roles. }\end{array}$ & $\begin{array}{l}\text { (Aasrum et al. } \\
\text { 2016) }\end{array}$ \\
\hline $\begin{array}{l}\text { Project } \\
\text { uncertainty }\end{array}$ & $\begin{array}{l}\text { Failing to fully understand the scope of work } \\
\text { packages, therefore, losing project control status. }\end{array}$ & $\begin{array}{l}\text { (Riley and } \\
\text { Horman 2001) }\end{array}$ \\
\hline $\begin{array}{l}\text { Client's } \\
\text { operational } \\
\text { capability }\end{array}$ & $\begin{array}{c}\text { Business competencies affiliated with active } \\
\text { participation and the right mandate on decision- } \\
\text { making. }\end{array}$ & $\begin{array}{l}\text { (Knapp et al. } \\
\text { 2014) }\end{array}$ \\
\hline Change orders & $\begin{array}{l}\text { Work that is added to or removed from the original } \\
\text { scope of work, as defined in the original contract. }\end{array}$ & $\begin{array}{l}\text { (Matthews et al. } \\
\text { 2018) }\end{array}$ \\
\hline Trust & $\begin{array}{l}\text { Facilitator of mutual openness in terms of behavior } \\
\text { and cohesion. }\end{array}$ & $\begin{array}{l}\text { (Bond-Barnard } \\
\text { et al. 2018) }\end{array}$ \\
\hline $\begin{array}{l}\text { Clear roles and } \\
\text { processes }\end{array}$ & $\begin{array}{l}\text { Roles, standardized processes, value mapping and } \\
\text { learning to establish an integrated coalition. }\end{array}$ & $\begin{array}{l}\text { (Erdogan et al. } \\
\qquad 2008)\end{array}$ \\
\hline $\begin{array}{l}\text { Physical and } \\
\text { cultural proximity }\end{array}$ & $\begin{array}{l}\text { Physical and geographical co-location of members } \\
\text { recognizing inherent personality differences to achieve } \\
\text { a close exchange of information. }\end{array}$ & $\begin{array}{l}\text { (Koolwijk et al. } \\
\text { 2018) }\end{array}$ \\
\hline $\begin{array}{l}\text { Alignment of } \\
\text { incentives }\end{array}$ & $\begin{array}{l}\text { Mechanisms of positive stimulation to improve } \\
\text { performance to be the same win-win community. }\end{array}$ & $\begin{array}{l}\text { (Schöttle and } \\
\text { Gehbauer 2012) }\end{array}$ \\
\hline $\begin{array}{l}\text { Commitment to } \\
\text { project }\end{array}$ & $\begin{array}{l}\text { Attitudes of mutual support to increase genuine } \\
\text { interest and set stakeholder priorities. }\end{array}$ & $\begin{array}{l}\text { (Tillmann et al. } \\
\text { 2012) }\end{array}$ \\
\hline Goal congruence & $\begin{array}{l}\text { Identification of clear objectives to achieve relational } \\
\text { efficiency in obtaining results. }\end{array}$ & $\begin{array}{l}\text { (Schöttle and } \\
\text { Tillmann 2018) }\end{array}$ \\
\hline $\begin{array}{l}\text { Conflict } \\
\text { resolution }\end{array}$ & $\begin{array}{l}\text { Competencies for the business continuity of a } \\
\text { challenging relationship with disputes at the front-end. }\end{array}$ & (Vaaland 2004) \\
\hline $\begin{array}{l}\text { Expectations } \\
\text { fulfillment }\end{array}$ & $\begin{array}{c}\text { Perception of service based on expected return } \\
\text { management. }\end{array}$ & $\begin{array}{l}\text { (Tillmann et al. } \\
\text { 2011) }\end{array}$ \\
\hline
\end{tabular}




\section{RESEARCH METHOD}

Collaboration and collaborative practices are produced by actors' experiences and social interactions with other actors. Therefore, an abductive and qualitative research approach was selected for this research. Semi-structured interviews using the critical incident technique (CIT) were selected as the data collection method. By incident is meant any observable human activity that allows inferences to be made. To be critical, the incident must have significance and depict the phenomenon being investigated (Flanagan 1954). CIT was employed to seek expert knowledge and experience of the constituents of collaboration. CIT enables the possibility to gather critical incidents from interviewees' narratives. Therefore, the interviews were designed to reveal memorable incidents regarding collaboration, or lack of collaboration, illustrated by empirical explanations. Interviewees were selected based on their proven experience in design and construction, and a seniority level ranging from middle management to decision-makers. Data were later analyzed using a mixture of deductive and inductive coding. Therefore, the most important factors of collaboration were compared with factors found in the literature.

Finally, the scenario-axis technique was deployed to construct scenarios for collaboration. This technique is recommended to systematically construct images of the future. The method aims to identify the most uncertain and impactful driving forces that could have a decisive output in the dependent variable under study (van't Klooster and van Asselt 2006). If two influential forces were identified, it was possible to use the technique to map collaborative environments within a construction project. The result is a $2 \times 2$ matrix that forms four quadrants which are the basis of four possible outcomes. These quadrants are then developed into scenario narratives, reflecting the influence of the previously identified critical incidents. Finally, the scenarios were discussed through implications to demonstrate their impact on collaborative lean management practice.

\section{DATA ANALYSIS AND RESULTS}

\section{EMPIRICAL VALIDATION}

Thirteen participants from the Peruvian construction industry were recruited and a total of 11 hours of recorded interviews were obtained. The interviewees' professional experience ranged from 7 to 25 years, and $30 \%$ of them had extensive lean construction practice. They had roles such as project managers, project engineers, chief executive officers, site engineers, and others. Data were carefully transcribed, resulting in 105 pages of content. The interviews were anonymized and stored in a data management system. Data were analyzed using MAXQDA 2020. Transcripts were loaded onto the system to start the coding process. Nodes were created based on the theoretical themes as described in Table 1. Transcripts were analyzed by assigning texts to nodes. However, during the data analysis process, up to eighteen nodes inductively emerged. Therefore, a factor reduction procedure was performed. The nodes with the highest number of evidence from data were retained for the analysis and a subnode level was created according to sample correlation. Moreover, the terminology was revised, the node-subnode association was revisited and grouped where appropriate. Table 2 shows the results of the data analysis, including a quote sample from the data. 
Table 2: Empirical results for collaboration factors

\begin{tabular}{|c|c|c|c|}
\hline Node & No. & Subnode & Quote Sample \\
\hline \multirow{3}{*}{ Trust } & 1 & $\begin{array}{l}\text { Achievement } \\
\text { capacity }\end{array}$ & $\begin{array}{l}\text { "An achievement translates into greater belief to } \\
\text { perform the work assigned for you, for the company } \\
\text { and your customers" }\end{array}$ \\
\hline & 2 & $\begin{array}{l}\text { Physical and } \\
\text { cultural } \\
\text { proximity }\end{array}$ & $\begin{array}{c}\text { "Rapid interaction of a formal and informal nature } \\
\text { between team members is made possible for the value } \\
\text { realization" }\end{array}$ \\
\hline & 3 & $\begin{array}{l}\text { Quality of } \\
\text { communication }\end{array}$ & $\begin{array}{l}\text { "Having transparent and open discussions from the } \\
\text { beginning enables more power to understand the } \\
\text { situation and expose your problems freely" }\end{array}$ \\
\hline \multirow{3}{*}{$\begin{array}{c}\text { Project } \\
\text { uncertainty } \\
\text { management }\end{array}$} & 4 & $\begin{array}{c}\text { Goal } \\
\text { congruence }\end{array}$ & $\begin{array}{l}\text { "Need to generate a common understanding of the } \\
\text { value generated throughout the supply chain" }\end{array}$ \\
\hline & 5 & Change orders & $\begin{array}{l}\text { "Mandatory to manage change orders under a triangle } \\
\text { of compromise, technical flexibility and negotiation" }\end{array}$ \\
\hline & 6 & $\begin{array}{l}\text { Conflict } \\
\text { resolution }\end{array}$ & $\begin{array}{c}\text { "Knowing from the start what will happen in a dispute } \\
\text { preserves peace of mind and reduces future } \\
\text { controversies" }\end{array}$ \\
\hline \multirow{3}{*}{$\begin{array}{l}\text { Client's } \\
\text { operational } \\
\text { capability }\end{array}$} & 7 & $\begin{array}{l}\text { Clear roles and } \\
\text { processes }\end{array}$ & $\begin{array}{c}\text { "Creates boundaries between functions and } \\
\text { procedures that condition the development of value } \\
\text { engineering" }\end{array}$ \\
\hline & 8 & $\begin{array}{l}\text { Alignment of } \\
\text { incentives }\end{array}$ & $\begin{array}{l}\text { "Increase performance by enhancing the value people } \\
\text { place on goals, causing them to engage more strongly } \\
\text { with those goals and achieve them" }\end{array}$ \\
\hline & 9 & $\begin{array}{c}\text { Team } \\
\text { empowerment }\end{array}$ & $\begin{array}{c}\text { "Grows reciprocal respect between people's opinions } \\
\text { because it provides autonomy and responsibility to } \\
\text { acquire the required skills" }\end{array}$ \\
\hline \multirow{2}{*}{$\begin{array}{l}\text { Business } \\
\text { relationships }\end{array}$} & 10 & $\begin{array}{l}\text { Intra- } \\
\text { organizational } \\
\text { support }\end{array}$ & $\begin{array}{c}\text { "Initial and ongoing senior management support and } \\
\text { secondly in terms of gaining the support of other parts } \\
\text { of the organization/peers" }\end{array}$ \\
\hline & 11 & $\begin{array}{l}\text { Expectations } \\
\text { fulfillment }\end{array}$ & $\begin{array}{l}\text { "Keep all parties informed of the overall service to be } \\
\text { provided to avoid disappointment" }\end{array}$ \\
\hline
\end{tabular}

\section{A SCEnARIO-BASEd MOdeL}

The next step is to conflate the emerging nodes from Table 2 into two complementary and independent intersecting axes. Briscoe et al. (2004) argued that clients are key drivers of performance improvement and innovation. Therefore, they are the most significant actor in achieving integration in the supply chain. However, these ideas have been debated and currently, researchers are investigating whether innovations should be client-led or supply-led (Lindblad and Guerrero 2020). Therefore, the emerging nodes were subsequently divided into two key uncertainties 'client attributes' and 'supply chain capabilities' as depicted in Figure 1. The inclusion of the nodes into two groups was based on the interview data which suggested an asymmetry between supply and demand maturity/capability. Moreover, to determine the appropriate axes, the approach was to uncover the relationship between the connection of the emerging themes and the axes.

For example, an interviewee highlighted an experience where physical proximity was crucial to reduce the latency in a major mechanical, electrical, and plumbing (MEP) clash in the field. The client went to the construction site and provided feedback to resolve the 
issue which was approved within a few minutes, compared to the traditional 4 days. However, this is still a rare practice as most contractors send requests for information (RFIs) to clients through the supervision/project management teams. The lack of clear communication between contractors and clients is also depicted as follows. A contractor sent several RFIs requesting clarification on how trucks will access a showroom in a retail project. However, the client's project manager responded that such requested change was not part of the scope. However, upon completion, the client noticed the problem and blamed the contractor for the error. Therefore, this situation shows a lack of project understanding and miscommunication between actors as the main barriers to effective collaboration. Moreover, most interviewees described that clients do not have clear design criteria and make constant changes even during construction. Thus, in practice, projects resemble the fast-track delivery method. This problem escalates when clients are unwilling to pay for the additional costs for design and construction changes. An architect said, "I know the client will change the layout 6 or 7 times; thus, I charge these costs in advance". From the narratives above, actors are focused on action and deliverables rather than on collaborative decision-making. For this reason, tensions emerge between the appointing party (client) and the appointed party (architects, engineers, contractors, and subcontractors).

The analysis then involved compiling names for each of the quadrants depicted in Figure 1. Following a logic of internal consistency together with a logic of cause and effect, scenarios were described using elements from the interviews (van't Klooster and van Asselt 2006). Below, we discuss these plausible events that were constructed from the data.

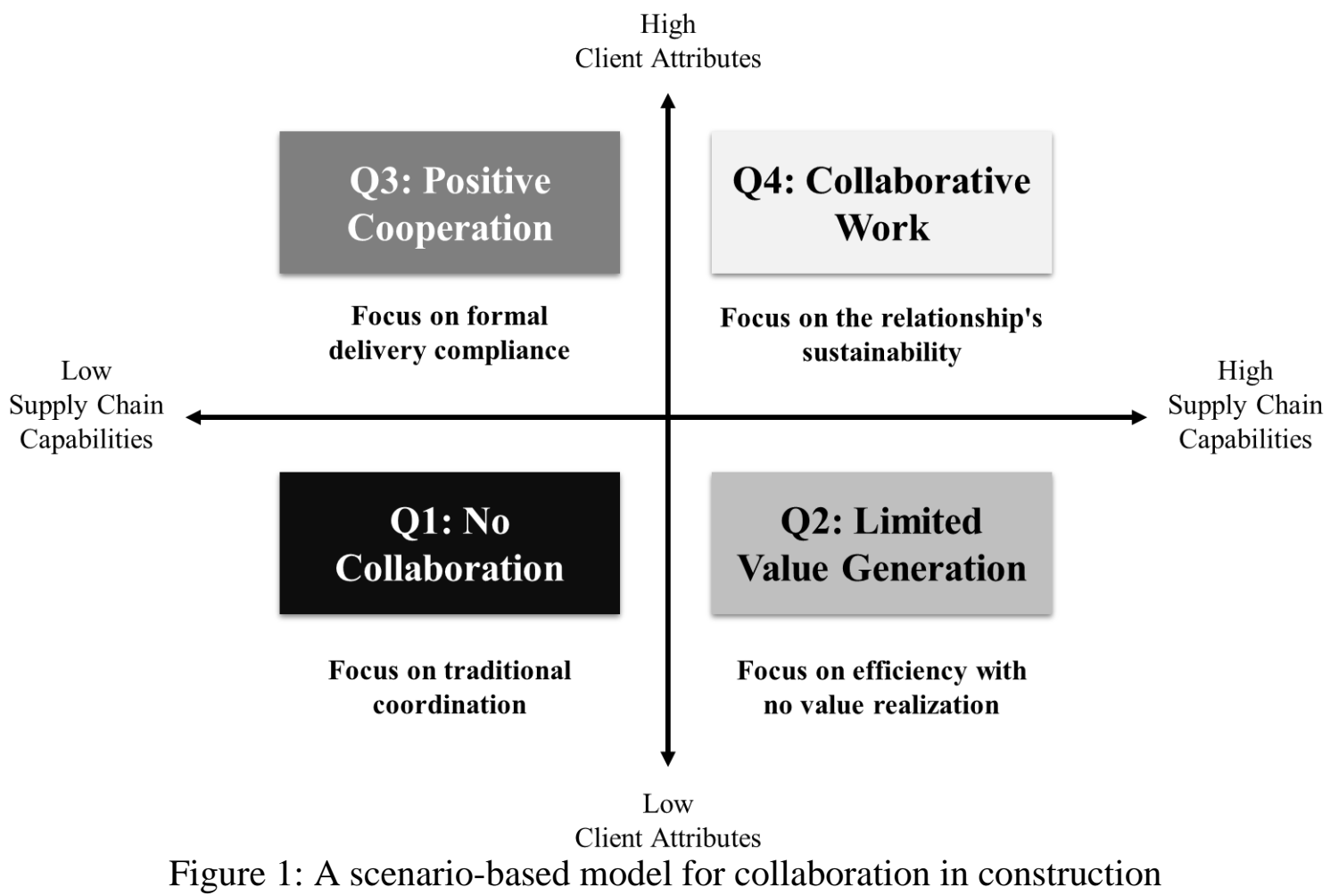

\section{Collaborative Work (High Client Attributes/High Supply Chain Capabilities)}

Collaboration is underpinned by value-based relationships with symmetric power and profuse information and knowledge exchange throughout the project lifecycle. The 
intersection between client/project objectives and operational processes have been well defined. There is a high degree of shared expertise at all organizational levels with clear corporate commitment and leadership cascading throughout project activities. The task of creating an integrated culture is based on organizational-driven policies. This scenario depicts IPD projects with a focus on long-term project outcomes.

\section{Limited Value Generation (Low Client Attributes/High Supply Chain Capabilities)}

This scenario is defined by a focus on efficiency with unknown value realization to the client. The supply chain demonstrates competencies in the use of cutting-edge platforms and digital engineering tools, as well as building information modeling and integrated concurrent engineering. The client, on the other hand, requests a project to be built on budget and on time. Small subcontractors might not be ready to collaborate, but they are integrated into the network by big players such as a DB contractor.

\section{Positive Cooperation (High Client Attributes/Low Supply Chain Capabilities)}

This scenario focuses on processes that deal with unbalanced interaction between teams and deliverables, whilst striving to maintain project compliance. This scenario depicts the digital divide between small and large firms. Designers and contractors do not possess the same maturity to deliver information and exchange knowledge. Thus, collaboration is limited by their capabilities. Normally, the most powerful firm acts as a system integrator.

\section{No Collaboration (Low Client Attributes/Low Supply Chain Capabilities)}

This scenario is cost- and time-driven, dominated by the traditional status-quo. Information is subject to basic coordination and knowledge exchange is minimal to nonexistent. It also features a top-down relationship based on DBB contracts and lump sum subcontracting. There is unknown value generation, opportunistic behaviour, and relationships are based on tough contracts that protect the most powerful actor.

\section{DISCUSSION}

To map the existing collaborative environments within construction projects, we aimed to develop a scenario-based model for inter-organizational collaboration. Based on the scenario narratives, this section discusses demand and supply relationships, lean construction tools and techniques, and opportunities in each scenario. First, in Q1 we might observe real estate developers with a focal interest in the business' return on investment. Therefore, there is a structural fragmentation between design and construction, and a disparity between the client's objectives (if any) and the contractor's operation (Schöttle and Gehbauer 2012). In Q2 we might see a DB contractor leading lean and digital implementation, and a client unaware or unwilling to be part of collaborative practices. Therefore, the DB contractor retains the benefits. In Q3, we might see a forward-looking client, but noticeable disparities within the supply chain. For example, in Peru, some clients are being aware of implementing Lean Construction, Building Information Modeling (BIM) and Virtual Design and Construction (VDC). However, there is a substantial gap between designers' and contractors' capabilities, with most major contractors being the leaders in implementing collaborative practices. Q4 is still an ideal scenario with very few examples in practice. However, Q4 is driven by preexisting trust between the client, designer, and contractors with a focus on long-term relationships (Tillmann et al. 2012).

The scenarios could also help establish roadmaps for Lean, BIM, and VDC implementation. Some tools and techniques outlined here can be applied in one or even 
all the quadrants. Given the limited possibility to collaborate at the project level, contractors might implement the Last Planner System (LPS) in Q1 to achieve better collaboration with subcontractors at the operational level (Schöttle and Tillmann 2018). Moreover, contractors can create BIM models to detect clashes and for quantity take-off which is sometimes considered as the first step into BIM implementation. In Q2, contractors can implement Target Costing in the early project stages. In that sense, this would reduce risks and ensure profitability for the contractor, but little value is passed on to the client. Additionally, this is a rich environment for lean design management with BIM (Aasrum et al. 2016) for both synchronous (integrated concurrent engineering) and asynchronous collaboration (common data environments). Moreover, DB contractors are engaged early in the project and off-site solutions are used in the design. In Q3, there is an opportunity to include client decisions using Target Value Design (TVD) to manage product profitability during product development and to reduce uncertainty and risk (Riley and Horman 2001). Also, Choosing by Advantages (CBA) would be used to bring actors with lower capabilities towards a more collaborative environment. From there, it drives the pathway towards Q4 that leverages previous tools within financial incentives and moves from project outputs to social, environmental, and economic outcomes.

Finally, some practical implications were identified for each scenario. In Q1, there is a potential for lean design management with BIM by convincing the client of the need for more collaborative approaches. This would move clients and contractors towards Q2 and Q3. In Q2, there is a potential to engage the client in lean and BIM applications in the operation and maintenance stage, and collecting lessons learned from facility managers from previous projects (Murguia et al. 2020). By doing so, the client's attributes would improve, and supply chains would move towards Q4. Supply chains within Q3 would benefit if the focus changes from cost and time to end-user satisfaction. Finally, Q4 supply chains have the imperative to transform the industry by developing new business models from one-off transactions to long-term partnerships. The scenarios would also be used as a training tool to raise awareness on collaboration in construction.

\section{CONCLUSIONS}

This study aimed to develop a model for inter-organizational collaboration. In practice, the common belief of collaboration is referred to perform outstanding coordination to achieve a common goal. It implies that parties should be willing to share information and knowledge for the greater project good. However, adversarial relationships and opportunistic behaviors stand in sharp contrast to delivering value and establishing a longterm business relationship. Primary data showed that collaboration can be established by improving the client's operational capacity, reinforcing strategies to reduce project uncertainty, promoting trust, and developing partnerships over time. Moreover, inductive analysis of interview data suggested that collaboration practice is a tension between client's and supply chains' technological, operational, and contractual capabilities. As such, four scenarios were developed based on low/high capabilities of clients and supply chains, namely 'Collaborative Work', 'Limited Value Generation', 'Positive Cooperation' and 'No Collaboration'. The knowledge of these collaboration factors and four scenarios would provide valuable insights for practitioners. For example, clients would understand their current position and formulate strategies to improve their technological, operational, and contractual capabilities to form more collaborative relationships with supply chains. Likewise, contractors and designers would deliver more value by strategically implementing Lean, BIM, and VDC methods, educating clients and developing business 
models that support collaboration. Future research would scrutinize case studies in each scenario to provide richer insights into how collaborative practices evolve.

\section{ACKNOWLEDGMENTS}

We would like to thank the interviewees for sharing their experience with us.

\section{REFERENCES}

Aasrum, J., Lædre, O., Svalestuen, F., Lohne, J., and Plaum, S. (2016). "Communication in building design management: A comparative study of Norway and Germany." In: Proc. 24th Annual Conference of the International Group for Lean Construction, Boston, MA, USA, 43-52.

Bond-Barnard, T. J., Fletcher, L., and Steyn, H. (2018). "Linking trust and collaboration in project teams to project management success." International Journal of Managing Projects in Business, 11(2), 432-457.

Briscoe, G. H., Dainty, A. R. J., Millett, S. J., and Neale, R. H. (2004). "Client-led strategies for construction supply chain improvement." Construction Management and Economics, 22(2), 193-201.

Deep, S., Gajendran, T., and Jefferies, M. (2019). "A systematic review of 'enablers of collaboration' among the participants in construction projects." International Journal of Construction Management, 1-13.

Erdogan, B., Anumba, C. J., Bouchlaghem, D., and Nielsen, Y. (2008). "Collaboration Environments for Construction: Implementation Case Studies." Journal of Management in Engineering, 24(4), 234-244.

Eskerod, P., Denmark, S., Dalcher, D., and Sandhawalia, B. (2010). "The role of project collaboration quality and knowledge integration capability in multi-partner projects." Paper presented at PMI ${ }^{\circledR}$ Research Conference: Defining the Future of Project Management, Project Management Institute, Washington, DC, 1-18.

Flanagan, J. C. (1954). "The critical incident technique." Psychological Bulletin, 51(4), 327-358.

Haaskjold, H., Andersen, B., Lædre, O., and Aarseth, W. (2019). "Factors affecting transaction costs and collaboration in projects." International Journal of Managing Projects in Business, 13(1), 197-230.

Haghsheno, S., Budau, M. R.-D., and Russmann, E. (2020). "Collaboration Barometer Development of a Tool for Measuring Collaboration During Design and Construction." In: Proc. 28th Annual Conference of the International Group for Lean Construction, Berkeley, California, USA, 323-336.

Hughes, D., Williams, T., and Ren, Z. (2012). "Differing perspectives on collaboration in construction." Construction Innovation, 12(3), 355-368.

Karlsson, A., and Kindbom, I. (2018). "Collaboration between project owners and contractors during the tender process in the construction industry (Master Thesis)." Jonkoping University International Business School.

Knapp, S., Long, D., and Howell, G. (2014). "The role of the Owner's Representative on IPD projects." In: Proc. 22nd Annual Conference of the International Group for Lean Construction, Oslo, Norway, 1369-1377.

Koolwijk, J. S. J., van Oel, C. J., Wamelink, J. W. F., and Vrijhoef, R. (2018). "Collaboration and Integration in Project-Based Supply Chains in the Construction Industry." Journal of Management in Engineering, 34(3). 
Lindblad, H., and Guerrero, J. R. (2020). "Client's role in promoting BIM implementation and innovation in construction." Construction Management and Economics, Routledge, 38(5), 468-482.

Matthews, J., Love, P. E. D., Mewburn, J., Stobaus, C., and Ramanayaka, C. (2018). "Building information modelling in construction: insights from collaboration and change management perspectives." Production Planning and Control, 29(3), 202216.

Murguia, D., Felix, K. M., and Guerra, M. A. (2020). "An approach to capture design and construction lessons learned from facility managers." In: Proc. 28th Annual Conference of the International Group for Lean Construction 2020, 997-1008.

Ozorhon, B., and Oral, K. (2017). "Drivers of Innovation in Construction Projects." Journal of Construction Engineering and Management, 143(4), 04016118.

Riley, D., and Horman, M. (2001). "The effects of design coordination on project uncertainty." In: Proc. 9th Annual Conference of the International Group for Lean Construction, Singapore, Singapore, 1-8.

Roberts, N. C., and Bradley, R. T. (1991). "Stakeholder Collaboration and Innovation: A Study of Public Policy Initiation at the State Level." The Journal of Applied Behavioral Science, 27(2), 209-227.

Schöttle, A., and Gehbauer, F. (2012). "Incentive systems to support collaboration in construction projects." In: Proc. 20th Conference of the International Group for Lean Construction, San Diego, California, USA.

Schöttle, A., Haghsheno, S., and Gehbauer, F. (2014). "Defining cooperation and collaboration in the context of lean construction." In: Proc. 22nd Annual Conference of the International Group for Lean Construction, Oslo, Norway, 1269-1280.

Schöttle, A., and Tillmann, P. A. (2018). "Explaning the benefits of team-goals to support collaboration." In: Proc. 26th Annual Conference of the International. Group for Lean Construction, Chennai, India, 432-441.

Tillmann, P. A., Tzortzopoulos, P., Miron, L. I. G., and Formoso, C. T. (2011). "The challenges of managing stakeholder requirements in a urban regeneration project." In: Proc. 19th Annual Conference of the International Group for Lean Construction, Lima, Peru, 362-371.

Tillmann, P., Ballard, G., Tzortzopolous, P., and Formoso, C. (2012). "How integrated governance contributes to value generation - Insights from an IPD case study." In: Proc. 20th Conference of the International Group for Lean Construction.

Vaaland, T. I. (2004). "Improving project collaboration: start with the conflicts." International Journal of Project Management, 22(6), 447-454.

van't Klooster, S. A., and van Asselt, M. B. A. (2006). "Practising the scenario-axes technique." Futures, 38(1), 15-30.

Willis, D., and Alves, T. da C. L. (2019). "Contracting for collaboration in construction." In: Proc. 27th Annual Conference of the International Group for Lean Construction, Dublin, Ireland, 809-818.

Xue, X., Zhang, R., Wang, L., Fan, H., Yang, R. J., and Dai, J. (2018). "Collaborative Innovation in Construction Project: A Social Network Perspective." KSCE Journal of Civil Engineering, 22(2), 417-427. 